\title{
Medical management of transgender children and adolescents
}

\author{
María Fernanda Castilla-Peón* \\ Medical Editorial Services, Hospital Infantil de México Federico Gómez, Mexico City, Mexico
}

\begin{abstract}
Transgender or gender incongruence (GI) persons identify themselves with a gender that is different from that correspondent to their birth sex. The demand for health services by families with transgender children or adolescents tends to increase. The prevalence of Gl in children is unknown; however, it has been estimated to be $>1 \%$ in adolescents. Transgender persons are at increased risk of depression, suicide, illicit drug abuse, human immunodeficiency virus infection, and non-accidental injuries. The most accepted model for the care of transgender persons assumes that these adverse outcomes are the consequence of social margination rather than the Gl condition itself. Social and physical gender transition seems to be effective in increasing the well-being of people with GI and reducing associated health risks. Mental health professionals can support the child in the process of social transition. The pediatric endocrinologist may offer puberty blockade and cross-sex induction of puberty. Surgical sex reassignment interventions are reserved for adults. Gender identity, gender expression, and sexual orientation are three relatively independent categories that can take any value, which is not necessarily binary (male/female) or fixed. Health professionals should be familiar with these concepts to offer the best resources available to optimize the well-being of each transgender child or adolescent with an individualized approach
\end{abstract}

Key words: Transgender persons. Gender incongruence. Sexual minority. Children. Adolescents. Cross-sex hormones.

\section{Manejo médico de niños y adolescentes transgénero}

\section{Resumen}

Las personas transgénero o con inconformidad de género (IG) se identifican a sí mismas con un género distinto al que les correspondería por su sexo al nacimiento. La demanda de servicios de salud de familias con niños o adolescentes transgénero va en aumento. La prevalencia de IG en niños no se conoce, pero se ha estimado que es mayor al $1 \%$ en adolescentes. Existe un elevado riesgo de depresión, suicidio, abuso de drogas ilícitas, infección por virus de inmunodeficiencia humana y lesiones no accidentales en estos sujetos. El modelo más aceptado para la atención de personas con IG asume que estos desenlaces adversos son producto de la marginación social y no de la condición de IG en sí. La transición de género de tipo social, así como la física, parecen ser efectivas para aumentar el bienestar de las personas con IG y reducir los riesgos en salud. Durante el proceso de transición social, los profesionales de la salud mental pueden apoyar al menor. Los endocrinólogos pediatras pueden ofrecer el bloqueo de la pubertad y la inducción contrasexual de la misma. Las intervenciones quirúrgicas de reasignación de sexo se reservan para mayores de edad. La identidad de género, la expresión de género y la orientación sexual son tres categorías relativamente independientes que pueden tomar cualquier valor no

\section{Correspondence:}

*María Fernanda Castilla-Peón

E-mail: fernandacastillapeon@gmail.com
Date of reception: 11-07-2017

Date of acceptance: 10-08-2017

DOI: 10.24875/BMHIME.M18000019
Available online: 12-07-2018 Bol Med Hosp Infant Mex. 2018;75:7-13

www.bmhim.com

2444-3409/@ 2018. Hospital Infantil de México Federico Gómez, published by Permanyer México SA de CV, all rights reserved. 
necesariamente binario (masculino/femenino) ni fijo. Los profesionales de la salud deben estar familiarizados con estos conceptos para ofrecer los mejores recursos disponibles y optimizar el bienestar de cada niño o adolescente transgénero de forma individualizada.

Palabras clave: Transgénero. Inconformidad de género. Minoría sexual. Hormonas contrasexuales. Niños. Adolescentes.

\section{Introduction}

According to the characteristics of their external genitalia at birth, nearly every baby can be assigned specific sex, male or female. Nevertheless, while sex is a condition that is known almost always at the moment of birth, and depends on verifiable biologic characteristics, gender identity is the subjective feeling of the person about being a boy or girl, or being between or beyond these two poles, masculine and feminine, which manifests at some point during life, generally after two years of age ${ }^{1}$.

Some people consider themselves as having a different gender than the one that was assigned according to their birth sex. Gender incongruence, gender variability or gender non conformity have been referred to as the situation in which the behaviors, appearance, and identity of a person do not match with those culturally assigned by their birth sex. People with gender incongruence (GI) can call themselves as transgender, or they can use other terms related to non-binary genders, such as gender-queer or gender fluid, among a long list that is continuingly evolving. As opposed to this, people in which gender identity is congruent to that of the assigned birth sex are denominated cisgender. It is noteworthy that the term gender incongruence, as well as other terms used throughout this text, are not universally accepted due to the effort of several groups to depathologize the transgender condition? ${ }^{2}$.

In few occasions, the newborn cannot be classified as a male or female due to ambiguity in the characteristics of the genitalia. These subjects have an alteration of sexual differentiation, according to medical terms, or with a intersexual state, as some people with this condition call themselves. This work deals with people with a male or female sex clearly defined at birth and not with people that have alterations of sexual differentiation.

It is important not to confuse gender identity with sexual orientation. Sexual orientation concerns with the sex towards which a person is attracted, romantically, erotically and sexually: towards those of the same gender, towards those of the opposite sex or both, being homosexual, heterosexual or bisexual, respectively (Fig. 1).

Thus, sex, gender identity, and sexual orientation are three different axes with their respective poles, and a person can have any combination of status in each one of them. Other terms that are worth knowing are presented in table 1.

\section{Epidemiology}

In some countries, there has been reported an increase in health services demand by under-aged people with $\mathrm{Gl}^{3,4}$, which is probably due to the increased access to information that children, adolescents, and their families have on the subject, and to the expanding tolerance of society towards gender diversity.

$\mathrm{Gl}$ can present from preschool age, although there are not reliable epidemiologic studies concerning the prevalence of this condition in children. The most recent population studies have reported a prevalence of adolescents that identify themselves as transgender between 1.2 and $1.3 \%^{5,6}$, and it is similar between birth-assigned male and females. It has been estimated that only around $27 \%$ of children with Gl persist with this condition until adulthood ${ }^{7,8}$. In contrast, not all adolescents or transgender adults refer a history of gender variability behavior during childhood. Prevalence of identification as a transgender decreases with age: in adults, it has been estimated between $0.5-1.1 \%^{2}$. Predictive factors for Gl persistence in adulthood are consistency, intensity, and persistence of transgender manifestations in children. Consistency should be understood as the presence of identification and transgender expressions in a repetitive manner in different forms and situations; persistence refers to the repetition of these behaviors through time as the child grows. Persistence during adolescence is the main predictor of Gl during adulthood ${ }^{9}$.

The number of people seeking specialized medical attention about gender affirmation is very low, and it has been reported to be between 1:11,900 to $1: 200,000^{10,11}$. Several reasons explain the disparity between the number of transgender adolescents and the demand for specialized medical services for the attention of gender affirmation. As previously mentioned, not all transgender subjects are interested in seeking specialized medical attention for interventions related to gender affirmation. However, it is important to recognize that stigmatization can discourage people from disclosing their transgender status and limit their access to health services of any kind. 


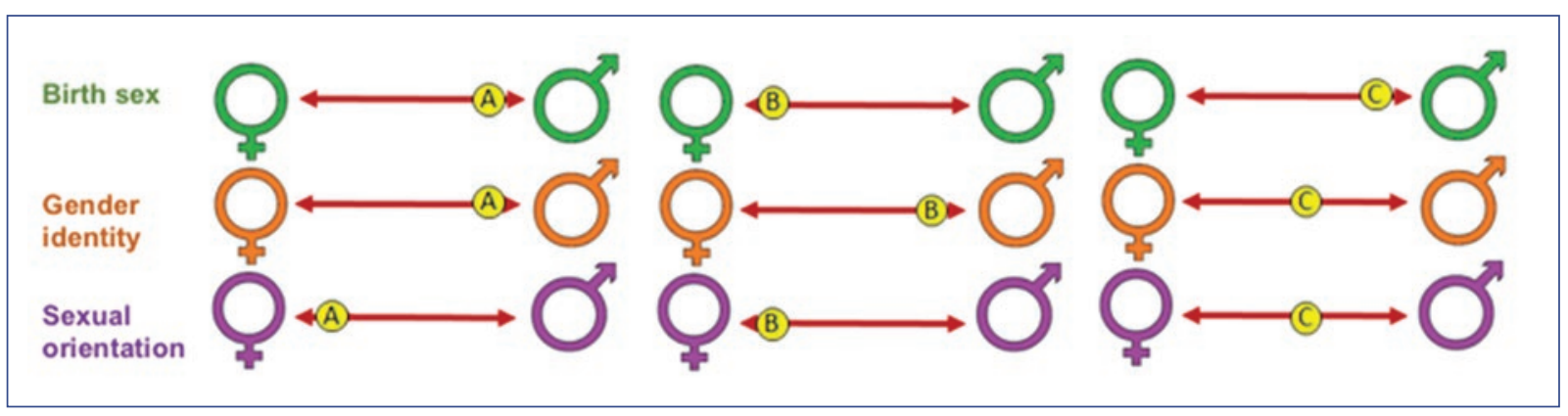

Figure 1. Sex, gender identity and sexual orientation are three different axes. A person may present with any combination of status in each one of the axis, and not necessarily located at any of the poles. A: A person of the male sex that identifies himself as a man and feels a sexual attraction to the female sex: heterosexual cisgender man. B: A person with female sex at birth that identifies herself as a man and feels attraction to the female sex: transgender man (FTM). C. Gender identity is not necessarily binary. This person of male sex at birth does not identify himself as having an exclusively female or male gender and additionally is bisexual.

While Gl is not a disease, transgender people are exposed to specific health risks. Transgender women have a $50 \%$ greater mortality than cisgender males, attributed, in part, to the increased mortality due to HIV, the use of illicit drugs and suicide. It has been reported that the suicide rate of transgender women is five times greater than the general population ${ }^{12}$ and that adolescents with Gl suffer from physical and emotional violence more frequently than their peers. Moreover, they present symptoms of depression and attempt suicide four to five times more frequently than cisgender people $^{2,13-17}$, and they are exposed to risky behaviors for health, such as alcohol consumption ${ }^{18}$ and early onset of sexual intercourse, two to three times more frequently than cisgenders. Also, it has been reported that they are unable to access to health services twice as often ${ }^{5}$. Female to male transgender individuals (FTM) can have eating disorders in an attempt to avoid a feminine-like silhouette. All this in a context of social disadvantage characterized by an increased frequency of loss of access to education, homelessness, unemployment, among others ${ }^{19-21}$.

Thus, it is evident that much can be done to improve well-being and health-related outcomes in the transgender population, and that attention must begin from the pediatric age.

\section{Healthcare of transgender children and adolescents}

The model of attention of prepubertal children with $\mathrm{Gl}$ has evolved through time from a vision in which this condition was regarded as a disease that must be "healed" to the most currently accepted, which attempts to offer resources to families to support children in their gender affirmation ${ }^{21,22}$. Some of the premises include the following:

1) Gender variants are not a disease

2) Gender can change, and it is frequently not binary (male/female)

3)Mental health or behavioral problems of the child generally have their origin in the negative reactions of society (transphobia) more than in him/her-self ${ }^{13,16,23}$. In this approach, the goal is to not pathologize the behavior or identity of children but to destigmatize gender variability, promote self-esteem and build safer spaces for them ${ }^{24}$

The attention of the children and adolescents with GI must be multidisciplinary and involve mental health professionals, social workers, and endocrinologists. It must be accounted that a person can choose from a range of possibilities regarding identity and gender expression without having to decide between two genders and that his identity and gender expression can change throughout time. Because of this, the approach must be individualized and complemented with an effort to understand the desires and expectations of each person regarding their body and the way of relating to others, to place the resources at their disposal and to achieve their goals in the best way possible.

\section{Gender transition and mental health}

$\mathrm{Gl}$ is not considered a mental disease neither by the Diagnostic and Statistical Manual of Mental Disorders (DSM-V) nor by the Endocrine Society. Still, the mental health professional can have an important role in the care of people with GI. The term gender dysphoria is 
Table 1. Terms related to the topic of gender variability

\begin{tabular}{|c|c|}
\hline Sex & $\begin{array}{l}\text { A person's biological state as a male or female: contemplates chromosomes, hormones, } \\
\text { gonads, and genitals. Cases in which these are not congruent or clearly defined represent } \\
\text { disorders of sexual differentiation (current medical term) }\end{array}$ \\
\hline Gender & $\begin{array}{l}\text { Psychological, cultural, and behavioral characteristics associated with the experience and } \\
\text { expression of the female or male gender }\end{array}$ \\
\hline Gender identity & $\begin{array}{l}\text { The subjective sensation of a person regarding being a man, woman or another state within } \\
\text { the gender spectrum }\end{array}$ \\
\hline Gender role & Behavior, attitude, and personality traits that a given culture designates as masculine or feminine \\
\hline Gender expression & The way a person externalizes his/her gender (for example, the way of dressing) \\
\hline $\begin{array}{l}\text { People with gender incongruence, } \\
\text { gender variability or transgender }\end{array}$ & $\begin{array}{l}\text { People with a gender identity that is not congruent with their sex at birth. They can refer to } \\
\text { themselves as transgender or with other terms related to non-binary genders (non-masculine/ } \\
\text { feminine) such as gender-queer, gender-fluid, androgynous or others }\end{array}$ \\
\hline Transsexual & $\begin{array}{l}\text { Individuals that have changed or are trying to change their secondary sexual characteristics } \\
\text { through medical interventions (hormones or surgery) and who permanently change their } \\
\text { gender role }\end{array}$ \\
\hline Affirmed gender & Corresponds to the gender that the person communicates to others as his/her real gender \\
\hline $\begin{array}{l}\text { Gender transition or gender affirmation } \\
\text { process }\end{array}$ & $\begin{array}{l}\text { The process of variable duration during which the person adopts characteristics considered } \\
\text { to be congruent with his/her gender identity. It comprises social aspects, such as dressing, } \\
\text { name, and official identification documents, and physical aspects, such as hormonal or } \\
\text { surgical treatments }\end{array}$ \\
\hline $\begin{array}{l}\text { Male to female transgender (MTF), a } \\
\text { transgender woman }\end{array}$ & $\begin{array}{l}\text { Individuals of male sex at birth, which gender identity is femenine. They can also be } \\
\text { referred to as transfeminine persons }\end{array}$ \\
\hline $\begin{array}{l}\text { Female to male transgender (FTM), a } \\
\text { transgender man }\end{array}$ & $\begin{array}{l}\text { Individuals of female sex at birth, which gender identity is masculine. They can also be } \\
\text { referred to as transmasculine persons }\end{array}$ \\
\hline Gender-fluid & $\begin{array}{l}\text { Refers to a person whose gender identity or expression changes between the female and } \\
\text { male or falls at any point within this spectrum }\end{array}$ \\
\hline Gender-queer & $\begin{array}{l}\text { A person whose gender identity does not correspond to that of a woman or a man but is in } \\
\text { between or beyond gender or a combination of both }\end{array}$ \\
\hline $\begin{array}{l}\text { Gender affirmation or reassignment } \\
\text { surgery }\end{array}$ & Surgery to change sexual characteristics to those concordant with the gender identity \\
\hline Gender dysphoria & Psychological discomfort associated with gender incongruence \\
\hline Gender identity disorder & $\begin{array}{l}\text { A diagnosis included in the Diagnostic and Statistical Manual of Mental Disorders (DSM-V) } \\
\text { replaced by "gender dysphoria" in the DSM-V (now in disuse) }\end{array}$ \\
\hline Cisgender & $\begin{array}{l}\text { A person whose gender identity is concordant with that of his assigned birth sex and, } \\
\text { therefore, does not experience gender incongruence }\end{array}$ \\
\hline
\end{tabular}

used to describe the psychological discomfort associated with the transgender condition. Thus, the goal of a mental health intervention is not to change gender identity but to help the child or adolescent with GI and their families to explore his/her identity to find the most comfortable role and gender expression, as well as to minimize the emotional discomfort associated with this process. Not everyone with $\mathrm{Gl}$ experiments gender dysphoria, and it is desirable that those who do be able to overcome it. Identifying and treating depression is a priority, as well as promoting self-esteem and developing positive strategies for integration to their environment, minimizing health risk behaviors.
Strategies directed at improving self-esteem of transgender children and adolescents and at reducing family, school, and social violence to which they are exposed have shown to be effective at decreasing many of the health risks associated with the transgender condition by increasing self-care, access to professional healthcare services, and by optimizing mental health ${ }^{20}$. Factors that have been associated with a lower probability of suicidal ideation and attempts in this group of people are family and social support, a low level of transphobia in the environment, and gender transition ${ }^{25}$. The process of gender transition or gender affirmation consists in the adoption of behaviors and body modifications 
congruent with gender identity. Evidence shows that gender transition in addition to hormonal therapy with or without surgical treatment is effective at improving gender dysphoria, decreasing suicide attempts and other psychiatric comorbidities, and improving the quality of life $e^{26,27}$. The mental health people who made a gender transition during childhood appears to be similar to that of the general population ${ }^{26,28}$.

The process of gender affirmation contemplates at least three modalities: social transition, hormonal interventions, and surgical interventions. Not every person with gender incongruence decides to go through the process of gender affirmation, and those who do, do not go through it in the same manner or through all its modalities. Therefore, an effort is required to understand what every individual desires and expects from both social and physical points of view.

Social transition refers to the process of adoption of a gender expression congruent to that of the gender identity; this may include changes in behavior, dressing, the use of name and pronouns, and even the change of documents and official identifications. It is important to evaluate the security of the environment in which the person lives to minimize the risk of social and violence, and not to jeopardize his physical, emotional or social integrity (loss of their jobs or access to education). In this phase, it is important to be accompanied by mental health professionals, social workers, school personnel and legal orientation, as well as being in contact with social organizations dedicated to promoting recognition of the rights of people with $\mathrm{Gl}$.

Gender affirmation interventions directed at physically modifying the body of people with gender nonconformity may be of a hormonal or surgical type. They are generally offered to interested people after having had a social gender transition, and with the close collaboration of the mental health professional and the rest of the team of professionals involved in the case, always focusing in the goals, fears, and expectations of the person and taking into account that these may change throughout time.

\section{Endocrine interventions}

Hormonal treatment of transgender people has been associated with a risk reduction of suicidal ideation from 53 to $28 \%$; that is, four persons would have to be treated to avoid a case of suicidal ideation ${ }^{25}$. It has been suggested that an earlier onset of physical transition (hormonal) may be associated with a better prognosis regarding the quality of life in comparison to a later onset ${ }^{29}$. The Endocrine Society, the World Professional Association for Transgender Health (WPATH), and the Group for Sexual Identity and Differentiation of the Spanish Society of Endocrinology and Nutrition have published several guidelines for the management of transgender children, adolescents, and adults ${ }^{10,30,31}$, which endorse the following recommendations.

The endocrinological approach is different depending on the stage of development of the user of healthcare services. Prepubertal children do not require any endocrinological intervention, except for closed surveillance of the first signs of puberty, which regularly occur between the age of 8 and 12 years in the female with the development of breast budding, and between the age of 9 and 13.5 years in the male, with the testicular growth. Physical examination by personnel familiarized with the process of puberty is important, given that the first signs of puberty can go unnoticed by untrained personnel.

Development of the secondary sexual characteristics may precipitate acute discomfort in children with GI. Gonadotropin-releasing hormone analogs $(\mathrm{GnRH})$, such as leuprolide, triptorelin, goserelin, and histrelin, inhibit the process of puberty by inhibiting pituitary stimulation for the production of testosterone or estrogen by the testicles or ovaries, respectively. By blocking puberty, irreversible changes caused by the sexual hormones (testosterone and estrogens) would be avoided. For the female, breast growth and widening of the pelvis. For the male, the growth of the penis and testicles would be avoided, as well as the virilization of facial features, the growth of the laryngeal cartilage (Adam's apple) and deepening of the voice, the appearance of facial hair, and a pronounced increase in muscle mass.

With halting the onset of secondary sexual characteristics correspondent to the sex of birth, time is gained for the adolescent to explore his gender identity, deal with gender dysphoria, decide if he/she desires a gender transition, and other decisions regarding the process of gender affirmation.

When starting $\mathrm{GnRH}$ analogs at an early stage of puberty (Tanner's stage II), the goal of avoiding virilization or feminization of the body is optimally achieved. If $\mathrm{GnRH}$ analogs are started in more advanced stages of puberty, changes that have already occurred in Tanner's stages III and IV cannot be reversed, but can be halted.

The high cost of $\mathrm{GnRH}$ analogs can make them inaccessible. Medroxyprogesterone is a lower cost alternative to $\mathrm{GnRH}$ but with some undesirable metabolic side effects. Additionally, skeletal maturation is not prevented, which can affect the final height. Masculine to femenine (FTM) transgender adolescents who are not receiving a 
puberty suppression scheme can be offered any antiandrogenic drug, such as spironolactone or cyproterone.

$\mathrm{GnRH}$ analogs have no permanent side effects in sexual characteristics. After a few months of suspension, the process of puberty continues as usual. This way, if the adolescent is not sure of his/her gender identity or the way he/she wishes to express it, $\mathrm{GnRH}$ analogs would give him/her time to think about it. Moreover, they can always be suspended to continue the development corresponding to the birth sex. GnRH analogs can alter the growth sprout associated with puberty and bone mineralization, although not enough information regarding its effects in height or the magnitude of the risk of osteoporosis in adulthood currently exists. $\mathrm{GnRH}$ analogs should not be used indefinitely (2 to 4 years) without sexual hormone replacement, given that the risk of osteoporosis in adulthood is increased. If the endogenous secretion of sexual hormones is planned to be kept inhibited, cross-sex hormone replacement should be started around 16 years of age; that is, with estrogens for MTF and testosterone for FTM. If the adolescent is still at an early age of pubertal development, puberty is blocked using $\mathrm{GnRH}$ analogs while initiating low doses of sex hormones, which are increased progressively. It is frequent for transgender individuals to be treated with sexual steroids without any medical supervision; sometimes at doses greater than recommended. Hormonal treatment must be started and supervised by a pediatric endocrinologist or a physician trained in the management of sexual hormones, with the goal of imitating, as best as possible, physiologic puberty, and monitoring hormone levels and adverse effects and to optimize final height. It is important that the adolescent understands the reversible and irreversible effects before initiating cross-sex hormonal treatment, as well as the risk of adverse events. Estrogens induce the irreversible growth of the breasts and pelvis. In FTM, testosterone induces facial hair growth, laryngeal growth (thickening of the voice) and growth of the clitoris, all of them irreversible. The reversible changes found to be induced by estrogens include a softer skin, decreased libido, and hypertriglyceridemia; and those by testosterone include seborrhea/acne, muscle mass hypertrophy, and increased libido. Estrogens increase the risk of thrombosis ${ }^{32}$, although this varies according to different doses and presentations. Other potential risks that have not been demonstrated are increased cardiovascular disease ${ }^{12}$, breast cancer, and prolactinomas. Testosterone can cause polycythemia, dyslipidemia, acne, infertility, liver enzymes elevation, androgenic alopecia and vaginal mucosa atrophy ${ }^{33}$.
The risk associated with the use of sex hormones should be evaluated individually considering the well-known risk of suicide and depression in people with GI without gender affirmation treatment.

\section{Surgical interventions}

Surgical treatments are definitive procedures, practicaIly irreversible. Guidelines by the Endocrine Society and the WPATH recommend not performing gender reassignment surgery before 18 years of age; moreover, they recommend that these be performed after a social transition and after one year of cross-sex hormonal treatment ${ }^{30}$. Although gender affirmation surgical procedures are not performed in the pediatric age, it is convenient for the health provider to be familiarized with these procedures to provide information if requested. Some gender affirmation surgical procedures include the following:

- Chest surgery. In the case of FTM, removal of the mammary tissue is performed; in the case of MTF, augmentation mammoplasty after one or two years of estrogen therapy.

- Genital reconstruction. In the cases of MTF, orchiectomy may allow the suspension of androgen production or action and to decrease estrogen dosage. Penectomy and vaginoplasty can also be performed. In FTM, a salpingo-oophorectomy with or without hysterectomy may be considered if the user desires, although there is no medical indication for the procedure. It is possible to construct a neopenis, neophallus or to perform a metoidioplasty, as well as a testicular prosthesis.

Other viable options include facial or hip plastic surgery, voice training, and depilation.

\section{Reproductive aspects}

While treatment with testosterone decreases fertility, FTM with uterus and ovaries may get pregnant, despite the latter treatment. Thus, it is important to prescribe an appropriate contraceptive method if necessary, as well as advising about the teratogenic effects of testosterone.

If the patient decides gamete preservation (eggs or spermatozoids), the probability of success is greater before starting contrasexual hormonal treatment and, evidently, before removal of the gonads (ovaries or testicles). It should be remembered that eggs preservation success is still limited ${ }^{34}$.

It has been suggested that progestogens contribute to the functional development of the mammary gland 
(lactogenesis), and there are protocols to induce breastfeeding beyond the puerperal period. Evidence regarding effectivity and safety around these interventions is still scarce.

\section{Conclusions}

The demand for healthcare services directly related to the condition of GI is increasing, even in the prepubertal stage. Therefore, healthcare personnel must be familiarized with the phenomenology of the transgender condition in general, and with the health issues and risks that this population faces, with the goal of improving the quality of attention and offering the best available resources to decrease the associated morbidities and improve their well-being.

\section{Funding}

None.

\section{Conflicts of interest}

The author declares no conflicts of interest.

\section{Acknowledgments}

To Mexico City's Council for Prevention and Elimination of Discrimination, for its work in recognition of the rights of the families of transgender children and adolescents.

\section{References}

1. Vance SR, Ehrensaft D, Rosenthal SM. Psychological and medical care of gender nonconforming youth. Pediatrics. 2014;134:1184-92.

2. Winter S, Diamond M, Green J, Karasic D, Reed T, Whittle S, et al. Transgender people: health at the margins of society. Lancet. 2016;388: 390-400.

3. Fernández Rodríguez M, Guerra Mora P, Martín Sánchez E, GISDEEN Group. Características de los menores de edad con disforia de género que acuden a la unidad de tratamiento de identidad de género. Rev Esp Salud Publica. 2017;91:1-9.

4. de Vries ALC, Cohen-Kettenis PT. Clinical management of gender dysphoria in children and adolescents: The Dutch approach. J Homosex. 2012;59:301-20.

5. Clark TC, Lucassen MFG, Bullen P, Denny SJ, Fleming TM, Robinson EM, et al. The health and well-being of transgender high school students: Results from the New Zealand adolescent health survey (youth'12). J Adolesc Health. 2014;55:93-9.

6. Shields JP, Cohen R, Glassman JR, Whitaker K, Franks H, Bertolini I. Estimating population size and demographic characteristics of lesbian, gay, bisexual, and transgender youth in middle school. J Adolesc Health. 2013;52:248-50.

7. Wallien MSC, Cohen-Kettenis PT. Psychosexual outcome of gender-dysphoric children. J Am Acad Child Adolesc Psychiatry. 2008;47:1413-23.

8. Drummond KD, Bradley SJ, Peterson-Badali M, Zucker KJ. A follow-up study of girls with gender identity disorder. Dev Psychol. 2008;44:34-45.

9. Olson-Kennedy J, Cohen-Kettenis PT, Kreukels BP, Meyer-Bahlburg R, Garofalo R, Meyer W, et al. Research priorities for gender nonconforming/transgender youth: gender identity development and biopsychosocial outcomes. Curr Opin Endocrinol Diabetes Obes. 2016;23:172-9.
10. Asociación Mundial para la Salud Transgénero. Normas de atención para la salud de personas trans y con variabilidad de género. World Professional Association for Transgender Health (WPATH); 2012.

11. Olson J, Forbes C, Belzer M. Management of the transgender adolescent. Arch Pediatr Adolesc Med. 2011;165:171-6.

12. Asscheman H, Giltay EJ, Megens JAJ, De Ronde W, Van Trotsenburg MAA, Gooren LJG. A long-term follow-up study of mortality in transsexuals receiving treatment with cross-sex hormones. Eur $\mathrm{J}$ Endocrinol. 2011;164:635-42.

13. Bockting WO, Miner MH, Swinburne Romine RE, Hamilton A, Coleman E. Stigma, mental health, and resilience in an online sample of the US transgender population. Am J Public Health. 2013;103:943-51.

14. Clements-Nolle K, Marx R, Katz M. Attempted suicide among transgender persons. J Homosex. 2006;51:53-69.

15. Nuttbrock L, Hwahng S, Bockting W, Rosenblum A, Mason M, Macri M, et al. Psychiatric impact of gender-related abuse across the life course of male-to-female transgender persons. J Sex Res. 2010;47:12-23.

16. Haas AP, Rodgers PL, Herman JL. Suicide attempts among transgender and gender non-conforming adult. Findings of the National Transgender Discrimination Survey. New York: American Foundation for Suicide Prevention; 2014

17. Perez-Brumer A, Hatzenbuehler ML, Oldenburg CE, Bockting W. Individual- and structural-level risk factors for suicide attempts among transgender adults. Behav Med. 2015;41:164-71.

18. Toibaro JJ, Ebensrtejin JF, Parlante A, Burgoa P, Freyre A, Romero M, et al. Infecciones de transmisión sexual en personas transgénero y otras identidades sexuales. Medicina (Buenos Aires). 2009;69:327-30.

19. Grant JM, Mottet L, Tanis J, Harrison J, Herman JL, Keisling M. Injustice at every turn. Natl Cent Transgender [Internet]. 2010;5:23. Available at: http://transequality.org/PDFs/NTDS_Report.pdf\%5Cnhttp://2fwww.thetaskforce.org/downloads/resources_and_tools/ntds_report_on_health.pdf

20. Hyde Z, Doherty M, Tilley PJM, McCaul K, Rooney R, Jancey J. The first Australian national trans mental health study: summary of results [Internet]. 2014. Available at: https://www.beyondblue.org.au/docs/default-source/research-project-files/bw0274.pdf.

21. Institute of Medicine. The health of lesbian, gay, bisexual, and transgender people [Internet]. Washington, DC: National Academies Press; 2011. Available at: http://www.nap.edu/catalog/13128.

22. Bonifacio HJ, Rosenthal SM. Gender variance and dysphoria in children and adolescents. Pediatr Clin North Am. 2015;62:1001-16.

23. Yadegarfard $M$, Meinhold-Bergmann ME, Ho R. Family rejection, social isolation, and loneliness as predictors of negative health outcomes (depression, suicidal ideation, and sexual risk behavior) among Thai male-to-female transgender adolescents. J LGBT Youth. 2014;11:347-63.

24. Hidalgo MA, Ehrensaft D, Tishelman AC, Clark LF, Garofalo R, Rosenthal SM, et al. The gender affirmative model: what we know and what we aim to learn. Hum Dev. 2013;56:285-90.

25. Bauer GR, Scheim Al, Pyne J, Travers R, Hammond R. Intervenable factors associated with suicide risk in transgender persons: a respondent-driven sampling study in Ontario, Canada. BMC Public Health. 2015;15:525.

26. Murad MH, Elamin MB, Garcia MZ, Mullan RJ, Murad A, Erwin PJ, et al. Hormonal therapy and sex reassignment: a systematic review and meta-analysis of quality of life and psychosocial outcomes. Clin Endocrinol (Oxf). 2010;72:214-31.

27. Weyers S, Elaut E, De Sutter P, Gerris J, T'Sjoen G, Heylens G, et al. Long-term assessment of the physical, mental, and sexual health among transsexual women. J Sex Med. 2009;6:752-60.

28. Olson KR, Durwood L, DeMeules M, McLaughlin KA. Mental health of transgender children who are supported in their identities. Pediatrics. 2016;137:e20153223.

29. Cohen-Kettenis PT, Van Goozen SHM. Sex reassignment of adolescent transsexuals: a follow-up study. J Am Acad Child Adolesc Psychiatry. 1997;36:263-71.

30. Hembree WC, Cohen-Kettenis P, Delemarre-Van De Waal HA, Gooren LJ, Meyer WJ, Spack NP, et al. Endocrine treatment of transsexual persons: an endocrine society clinical practice guideline. J Clin Endocrinol Metab. 2009;94:3132-54.

31. Moreno-Pérez Ó, Esteva De Antonio I. Guías de práctica clínica para la valoración y tratamiento de la transexualidad. Grupo de Identidad y Diferenciación Sexual de la SEEN (GIDSEEN). Endocrinol y Nutr. 2012;59:367-82.

32. Asscheman H, T'Sjoen G, Lemaire A, Mas M, Meriggiola MC, Mueller A, et al. Venous thrombo-embolism as a complication of cross-sex hormone treatment of male-to-female transsexual subjects: a review. Andrologia. 2014;46:791-5.

33. Weinand JD, Safer JD. Hormone therapy in transgender adults is safe with provider supervision. A review of hormone therapy sequelae for transgender individuals. J Clin Transl Endocrinol. 2015;2:55-60.

34. T'Sjoen G, Van Caenegem E, Wierckx K. Transgenderism and reproduction. Curr Opin Endocrinol Diabetes Obes. 2013;20:575-9. 